\title{
Amalia Rodríguez Somolinos, 'Voirement, de si haut si bas': proverbe, vérité et polyphonie en français médiéval
}

\section{Maria Colombo Timelli}

\section{(2) OpenEdition}

\section{Journals}

\section{Édition électronique}

URL : http://journals.openedition.org/studifrancesi/3650

DOI : 10.4000/studifrancesi.3650

ISSN : 2427-5856

Éditeur

Rosenberg \& Sellier

\section{Édition imprimée}

Date de publication : 1 décembre 2012

Pagination : 543-544

ISSN : 0039-2944

\section{Référence électronique}

Maria Colombo Timelli, « Amalia Rodríguez Somolinos, 'Voirement, de si haut si bas': proverbe, vérité et polyphonie en français médiéval », Studi Francesi [En ligne], 168 (LVI | III) | 2012, mis en ligne le 30 novembre 2015, consulté le 08 mars 2021. URL : http://journals.openedition.org/studifrancesi/3650 DOI : https://doi.org/10.4000/studifrancesi.3650

Ce document a été généré automatiquement le 8 mars 2021.

\section{cc) (†) $\odot$}

Studi Francesi è distribuita con Licenza Creative Commons Attribuzione - Non commerciale - Non opere derivate 4.0 Internazionale. 


\title{
Amalia Rodríguez Somolinos, 'Voirement, de si haut si bas': proverbe, vérité et polyphonie en français médiéval
}

\author{
Maria Colombo Timelli
}

\section{RÉFÉRENCE}

AMALIA RODRÍGUEZ SOMOLINOS, 'Voirement, de si haut si bas': proverbe, vérité et polyphonie en français médiéval, «Vox Romanica», 69, 2010, pp. 175-187.

1 Avec cet article A.R.S. continue sa réflexion sur les introducteurs de proverbes dans les textes en ancien et en moyen français (cf. «SF», 162, 2010, p. 527). Ici elle étudie, sur la base d'un corpus informatisé (Corpus de la littérature médiévale, Base textuelle de moyen français, Frantext) et de recherches personnelles, les emplois et fonctions de voirement, adverbe modal épistémique mettant l'accent sur la vérité du proverbe qu'il introduit. Son analyse se structure en trois points: les sens et emplois de voirement en français médiéval, les sens explicite et implicite de voirement (à savoir son rapport à la vérité et à la polyphonie), la présence non nécessaire de voirement (le proverbe étant vrai en soi). En conclusion, cet adverbe, qui ne peut pas fonctionner en emploi absolu, vient renforcer un énoncé déjà formulé par une voix autre, avec laquelle le locuteur confirme son accord. 